\title{
EVOLUȚII DEMOGRAFICE, RISCURI SOCIALE ȘI PARENTALITATE
}

\author{
Ecaterina CROITOR ${ }^{\odot}$, dr., lector univ., \\ Universitatea „Ștefan cel Mare” din Suceava, \\ doctorand, Universitatea A1.I.Cuza, Iași, România \\ DOI: $\underline{\text { https://doi.org/10.36004/nier.cdr.2019.14-11 }}$ \\ JEL Classification: I30, J11, J12, J13, J18.
}

Actualitate: Impactul evoluţilor demografice asupra riscurilor sociale este complex şi de multe ori identificat la câțiva ani după înregistrare, atunci când o problemă începe să afecteze tot mai multe persoane, devenind în timp un fenomen social. Schimbările profunde pe care le-au cunoscut populaţia şi fenomenele demografice au impact economic şi social, inclusiv în ceea ce privește parentalitatea.

Scop: Aspecte precum: controlul nașterilor (scăderea nașterilor prin contracepție sau avort, sau creșterea nașterilor prin fertilizare in vitro), numărul şi ponderea copiilor născuţi în afara căsătoriei, monoparentalitatea, divorțialitatea, starea de sănătate a populației și migrația masivă pentru muncă, influențează practica parentalității- văzută ca un cumul de sarcini specifice fiecărei zile pe care părinții îl îndeplinesc în procesul de creștere și educare a copilului.

Scopul cercetării este de a verifica dacă răspunsurile adaptative ale părintelui la schimbările demografice, permit acestuia o asumare conștientă a rolului parental, cu tot cu riscurile sociale derivate ce pot afecta membrii unei familii/comunități, iar pe de altă parte, permit copilului crearea sentimentului de individuare și identitate.

Metodele de cercetare au în atenție analiza aspectelor bio-psiho-sociale ale familiei în corelație cu schimbările demografice, raportate swot (puncte tari, punte slabe, oportunități, amenințări).

Rezultate: In toate tipurile de societăți, transmiterea de valori, de norme, de modele, presupune o „pregătire” a membrilor săi nu doar din punct de vedere biologic (incluzând capacitatea organismului de a procrea), ci și din punct de vedere psihic, economic și social.

Familia văzută ca sistem social format din indivizi legați prin legături afective și de loialitate din punct de vedere biologic, răspunde de transmiterea genetică care permite continuitatea speciei umane; din punct de vedere sociologic, este maniera de a face parte dintr-o comunitate, dintr-o populație, la bază fiind schimburile permanente influențate de educație și mediu, iar din punct de vedere psihologic, este matricea dezvoltării structurii psihice.

Cuvinte-cheie: parentalitate, schimbări demografice, risc social, modele parentale.

Actuality: The impact of demographic evolutions on social risks is complex and often identified a few years after registration, when a problem begins to affect more and more people, becoming in time a social phenomenon. The profound changes that the population has experienced and the demographic phenomena have economic and social impact, including in terms of parenting.

Purpose: Aspects such as: birth control (reduction of births through contraception or abortion, or the growth of in vitro fertilization births), number and share of children born out of wedlock, single parenting, divorciality, population health status and mass migration to work, influences parentality practice - seen as an accumulation of specific tasks to each day that parents fulfill in the process of raising and educating the child.

The purpose of the research is to check if the parent's adaptive responses to demographic changes allow him/her a conscious assumption of the parental role, with all the derived social risks that can affect the members of a family / community, and on the other hand, allow the child to create the feeling of individuation and identity.

\footnotetext{
${ }^{\circledR}$ Ecaterina Croitor, ecaterina_croitor@yahoo.com
} 
The research methods pay attention to the analysis of the bio-psycho-social aspects of the family in correlation with the demographic changes, reported swot (strengths, weaknesses, opportunities, threats).

Results: In all types of societies, the transmission of values, norms, models, implies a "training" of its members not only from a biological point of view (including the organism's ability to procreate) but also from a psychic, economic and social points of view.

The family, seen as a social system made up of individuals linked through affective and biological loyalty, is responsible for the genetic transmission that allows the continuity of the human species; from a sociological point of view, it is the way of being part of a community, of a population, based on the permanent exchanges influenced by education and environment, and from the psychological point of view, it is the matrix of the development of the psychic structure.

Key words: parentality, demographic changes, social risk; parental models.

Se spune că „,părintele este scribul care consemnează experienţele copilului și le reflectă astfel încât copilul poate să dea sens celor trăite" (Siegel D., Hartzell M. [17, p. 306]) iar înţelegerea de sine, alături de înțelegerea a ceea ce se întâmplă în exteriorul nostru influențează perspectiva pe care o avem asupra parentalității. În acest context, vom iniţia discuția despre parentalitate pornind de la semnificaţia familiei, analiza familiei tradiţionale şi a celei moderne, cu funcţiile şi disfuncţiile ei, pentru că dorinţa de înţelegere a modului în care familia funcţionează presupune în primul rând exploatarea ariilor de cuprindere ale acesteia şi înţelegerea contextului social în care ne plasăm. Schimbările apărute în cadrul familiei reprezintă şi un proces de adaptare la extinderea globalizării şi a gradului de integrare a pieţelor, furnizându-se astfel contextul politic şi economic pentru acestea, fără ca ele să înlocuiască neapărat familia cu o formă alternativă ci modificând anumite aspecte ale structurii sale existente.

Procesul de modernizare a instituţiei familiale este un proces de adaptare la schimbările produse de revoluţia industrială, de revoluţiile politice - dar, în acelaşi timp, familia a fost un participant activ, cu un rol esenţial în cristalizarea economiei, valorilor şi comportamentelor moderne. Emmanuel Todd (Todd E., 1992: 16, apud. Drăgan I., coord. [4]) demonstrează că societăţile au intrat mai devreme pe calea modernizării în funcţie de ce tip dominant de familie există în societatea respectivă. Astfel, sunt analizate: Anglia (familia nucleară, liberală, inegalitară); Germania (familia-tulpină, autoritară, inegalitară); Franţa (familia nucleară, liberală, egalitară); Italia (familia comunitară, autoritară, egalitară). Dintre aceste tipuri de familie, cea mai aptă pentru modernitate este familia nucleară, liberală şi inegalitară, dominantă în Anglia, deoarece acest tip asigură în mod optim mobilitatea indivizilor prin sistemul ei individualist, ce a permis ruperea cu uşurinţă de căminul familial şi, în final, dizolvarea întregii clase ţărăneşti şi a structurii feudale în Anglia, ce a devenit astfel prima putere industrială. Germania, deşi după invenţia tiparului era mai dezvoltată din punct de vedere cultural, nu a devenit prima putere industrială din raţiuni antropologice: tipul său dominant de familie cuprinde trei generaţii, cu copii strâns legaţi de familie, de patrimoniul ei economic şi cultural. Această familie era astfel prea puţin adaptabilă la transformări şi deplasări masive ca acelea cerute de revoluţia industrială.

Încercarea de a defini principalele trăsături ale familiei moderne, ne conduce spre convingerea că majoritatea acestora se integrează complexulului de valori, atitudini, norme şi comportamente ce caracterizează, în general, civilizaţia modernă. O analiză a lor pleacă de la următoarele aspecte:

1. Familia nu mai este o unitate de producţie economică.

2. Reducerea dimensiunii familiei prin restrângerea numărului de copii ai unui cuplu şi prin quasigeneralizarea familiei nucleare. Familiile restrânse sunt mai apte pentru mutaţiile sociale ale modernizării. Micşorarea dimensiunii familiei a provocat schimbări importante în stilul de viaţă, în comportamentele familiale. 
3. Mobilitatea matrimonială, scăderea autorităţii parentale a clanului, în general, şi creşterea rolului individului în decizia asupra momentului căsătoriei şi a alegerii partenerului. Datorită transferării unor funcţii ale familiei către alte instituţii sociale, raţiunile economice şi politice ale căsătoriei încep să-şi piardă din importanţă. O altă consecinţă a sporirii rolului individului în orientarea propriei vieţi de familie (şi a scăderii autorităţii şi controlului exercitate prin legăturile de rudenie) este şi răspândirea neolocalităţii (cuplurile nou formate pot locui unde vor nu neapărat în familia soţiei - matrilocalitate sau a soţului - patrilocalitate).

4. Schimbarea locului copilului în familie. Pe măsura ce mijloacele de producţie încep să devină mai complicate din punct de vedere tehnologic, munca copiilor începe să-şi piardă din importanţă, paralel cu scăderea ratelor de natalitate (Chesnais J.C., apud. Ghebrea G. [5]). Obligaţi în societatea tradiţională să lucreze de la vârste fragede (în gospodăria rurală sau în ateliere), copiii încep treptat să fie percepuţi nu ca forţă de muncă ci ca valoare în sine.

Una din cauzele determinante ale valorizării statutului copilului, ale creşterii costului său (financiar, afectiv şi de timp investit) este generalizarea şi obligativitatea educaţiei şcolare. Prelungirea acestei perioade în viaţa copilului determină centrarea problematicii copilului asupra formării sale şcolare.

5. Schimbări în solidaritatea familială.

Dacă în Evul Mediu, cauza principală a dezorganizării familiei era decesul unuia dintre soţi, în epoca modernă principala cauză începe să devină divorţul.

De exemplu, la mijlocul secolului al XVIII-lea jumătate din căsătorii se sfârşeau prin decesul unuia dintre soţi în Suedia, 60\% în Franţa, 70\% în India (Johnson A,G., apud Gherea G. [5]) Pe măsură ce ratele de mortalitate decad, divorţul devine forma majoră de disoluţie a familiei, Între 1860 şi 1984 rata divorţurilor în S.U.A. a crescut de la 1, 2/1.000 cupluri căsătorite la 23,1, modificându-se în acelaşi timp şi normele, valorile şi atitudinile referitoare la divorţ.

Modernitatea este diferită sau chiar opusă percepţiilor tradiţionale, referindu-se la produse ale culturii, instituţii, forme de organizare socială, moduri de comportare. Societatea modernă este mereu în schimbare, iar în momentul în care modul de viaţa tradiţional e înlocuit de unul mult mai complex, avansat tehnologic, modernitatea apare ca efect al acestor schimbări. Prin contrast, familia modernă se bazează pe individualism ca valoare (ceea ce explică creşterea spectaculoasă a numărului divorţurilor şi toleranţa din ce în ce mai mare faţa de acest fenomen social, femeia capată independenţa economică, copiii au un mai mare control asupra propriului destin). Pe lângă avantajele aduse de modernitate oamenii trebuie să facă faţă unor noi provocări, unor noi conflicte şi dezavantaje.

Valorile familiei moderne întemeiază un stil de viaţă distinct de cel al familiei tradiţionale: autorităţii i se substituie ca valoare centrală cooperarea. Şi ea este susţinută de valori ca: egalitatea, schimbarea, comunicarea. Familia modernă se caracterizează printr-o accentuată flexibilitate a structurii de autoritate şi putere. Nu mai există un model unic, dominant, în care bărbatul decide, atât în privinţa hotărârilor care vizează viaţa conjugală, cât şi a celor care privesc relaţia parentală, aşa cum se întamplă în tradiţionalitate. Relaţia modernă surprinde reciprocitatea puterii şi autorităţii, pe diferite nivele şi în diferite intensităţi, în contextul mai general al unui egalitarism afirmat şi, tot mai des, pus în practică. Autoritatea şi puterea în familia modernă se află într-un permanent proces de construcţie şi reconstrucţie, în funcţie de negocierile ce au loc între parteneri, de atitudinile si comportamentele acestora vis-a-vis de rolurile pe care le îndeplinesc în familie şi de statusurile ocupate în afara ei.

Într-un studiu efectuat de către Maria Simion, intitulat "Familia în Europa între 1960 şi 2000" [18], se remarcă faptul că România s-a aflat în 1960 în grupa fruntaşă privind nupţialitatea, rata primelor căsătorii; vârsta medie la prima căsătorie era una dintre cele mai joase în Europa, iar procentul naşterilor extraconjugale, unul dintre cele mai scăzute. Evoluţia ulterioară a acestor indicatori a avut loc în sens negativ, dacă se porneşte de la premisa că o nupţialitate ridicată şi un procent cât mai mic al naşterilor extraconjugale şi al divorţurilor sunt favorabile derulării pozitive a 
proceselor şi fenomenelor sociale, demografice, economice. În anii ce au urmat a avut loc o continuă scădere a nupţialităţii care a ajuns în 2001 la cea mai mică valoare postbelică, 5,8 \% \% În deceniul încheiat, nupţialitatea a scăzut cu un ritm de trei ori mai mare decât în cele trei decenii anterioare. $\mathrm{Cu}$ toate acestea, din punctul de vedere al nupţialităţii, România s-a situat permanent în grupul ţărilor cu valorile cele mai ridicate.

Rata primelor căsătorii a avut aproximativ aceeaşi evoluţie. Scăderea din perioada 19601990 a fost mai mare decât cea din deceniul următor, ritmul scăderii din cea de-a doua perioadă a deceniului fiind din nou, superior celei dintâi.

Deşi a crescut, ca şi în celelalte ţări europene, vârsta medie la prima căsătorie rămâne una dintre cele mai scăzute în Europa.

În ceea ce priveşte fenomenul divorţialităţii, acesta a luat o foarte mare amploare începând din secolul al XIX-lea, în special după cel de-al doilea război mondial, cu o creștere accentuată până în prezent. Paul Iluţ explică faptul că ,ridicarea accentuată a divorţialităţii în epoca actuală nu inseamnă că a crescut în aceeaşi măsură şi rata dezorganizării maritale întrucât în trecut erau multe cupluri destrămate (informal) dar care din cauza constrângerilor de tot felul nu divorţau" (Iluţ P. [8]), explicând în acelaşi timp că s-a înregistrat totuşi o creştere semnificativă a divorţurilor în societatea modernă faţă de cea tradiţională.

Cuplul modern a dobândit ,luciditatea tranzienţei fericirii sale” (Mitrofan I. [10]), optând pentru calitatea relaţiei în defavoarea durabilităţii sale cu orice preţ. Căsătoria dobândeşte progresiv o dimensiune relaţională, care aspirând spre optimizare, răspunde nevoii de construire a identităţii personale, în care fiecare dintre membrii cuplului devine „revelatorul” sinelui celuilalt. Dacă tendinţa spre optimizare şi de fapt realizarea acesteia nu este resimţită în cuplu, coeziunea familială scade treptat, iar partenerii, aflaţi în impas preferă să recurgă la divorţ pentru a-şi recâştiga libertatea( , divorţ fără vină" -no-fault divorce- îşi are deja poziţia bine stabilită în statisticile de specialitate).

În acest context și parentalitatea capătă noi dimensiuni adaptându-se unei societăţi într-o permanentă schimbare. Amintim că Freud exclude ideea separației între feminin și matern, între femeie și procreație (deși ulterior analizează și acceptă această posibilitate) şi aducem în atenţie constatarea faptului că femeile au dobândit în timp ,puterea de a aduce atingere caracterului sacru al sămânței masculine, pentru satisfacerea unei plăceri distincte de cea a maternității”" (Roudinescu E. [13, p. 133]), având posibilitatea la începutul secolului XXI să controleze numărul de nașteri, inclusiv să devină- dacă își doresc sterile. Tehnicile medicale de regularizare a nașterilor, tehnicile destinate împiedicării fecuntației sau fecundarea in vitro, reprezintă într-un fel mărturii ale scăderii substanțiale a numărul de copii născuți , din întâmplare”, fapt corelat ulterior, din ce în ce mai mult cu faptul că a deveni părinte survine într-o etapă de maturizare a adulţilor, apărând astfel şi termenul de parentalitate -ce este atribuit lui Benedeck- (parenthood) definit ca ,procesul de dezvoltare psiho-afectivă comun celor doi părinți prin conceperea unui copil” (Sellenet C. [16, p. 13]). Dezvoltând aceeași idee, apare definiția parentalității ca fiind ,,ansamblul reprezentărilor, afectelor și comportamentelor subiectului în relație cu copilul sau copiii săi, fie ei născuți, în burta mamei sau încă neconcepuți” (Stoleru și Huet M., apud Sellenet C. [16, p. 14])- constituit într-o evoluție ce cuprinde toate etapele vieții: copilăria, adolescența și vârsta adultă. De aceea conceptul interesează atât din punct de vedere psihologic- pentru că părintele poate deveni limitat în asumarea acestui rol din cauza problemelor personale - evenimente traumatice, boli, etc, dar și din punct de vedere sociologic, dacă ne raportăm la influența pe care care o are asupra situației sociale a copilului.

Practica parentalităţii este influenţată astfel de o serie de fenomene dintre care vom face referire la migraţie și sărăcie.

Dacă ne referim la venirea unui copil pe lume, menţionăm că aceasta îşi găseşte locul, în diferite forme, într-un ansamblu de rituri ale sarcinii ca şi ale naşterii, „simpatetice și contagioase, atât directe cât şi indirecte, dinamiste şi animiste, care au ca obiect uşurarea travaliului şi ocrotirea 
mamei şi copilului, deseori chiar a tatălui, a rudelor sau a întregii familii, ori a clanului în totalitatea sa împotriva influenţelor malefice, impersonale sau personificate" (Van Gennep A. [21, p. 48]). Deşi diferenţele nu sunt fundamentale de la o societate la alta, totuşi contextul este diferit- nu doar din punct de vedere cultural ci și din perspectiva regândirii relațiilor cu părinții, cu rețeaua de sprijin care presupune reorganizarea reprezentărilor de sine. Faptul de a deveni părinte într-o situație de migrare poate fi perceput ca „un episod dureros fără compensații, care nu se bazează pe reconfortări culturale și sociale construite de-a lungul timpului pentru a răspunde într-o manieră unică acestei experiențe universale." (Solis-Ponton L. [19, p. 366]). Părintele, imigrant- intrat într-o nouă cultură şi emigrant- care și-a părăsit cultura, devine extrem de vulnerabil în faţa unor constrângeri la care societatea care îl primește îl supune, stare pe care o transmite și copiilor săi. Exerciţiul parentalității devine dificil pentru că însuși părintele se simte fără sprijin sau neînțeles, iar dificultățile specifice migranților se suprapun peste probleme de sărăcie socială și economică îngreunând atât procesul de sintonizare a părintelui cu copilul (,cel neînţeles nu poate înțelege”) cât și procesul de adaptare socială și de integrare socio-profesională în țara de primire. În contextul migrării, pentru populațiile care vin din țări cu universuri culturale diferite, parentalitatea presupune atât traducere cât și recreare (Solis-Ponton L. [19, p. 369]). Metodele utilizate în educaţia copilului, modul şi perioada în care se face trecerea copilului de la simbioză ${ }^{18}$ (cu mama în special) la autonomie (Ruppert F. [15]), asumarea de către familia lărgită a funcției de dezvoltare a capitalului social sau simbolic al fiecăruia dintre membri sunt aspecte care construiesc parentalitatea - pe registrul filiației și afilierii şi în acelaşi timp o influențează. Dacă ne referim la migrația apărută din cauza lipsurilor financiare când unul dintre părinţi migrează, nu putem să nu amintim dificultăţile de asumare a parentalității și privarea copilului de prezența cotidiană a părintelui, chiar dacă ulterior, după o perioadă mai mult sau mai puțin îndelungată se realizează reîntregirea familială. În același context al migrării, dar pe un alt registru- atunci când copilul se naște în altă țară decât cea de origine, se vorbește (Moro M.R. [12]) despre riscul la care este supusă mama prin migrare, din cauza, ruperii acesteia de anturajul său cultural. Atunci când mama are o altă religie decât actualul grup din care face parte și alte modele parentale, ea se simte neînțeleasă, nesusținută, nu știe la ce gen de ritualuri să apeleze pentru a fi protejată- ea și copilul său, ceea ce împiedică construcția unei relații suficient de sigure între mamă şi copil necesară pentru dezvoltarea armonioasă din punct de vedere psihic, dar și fizic a copilului. Dificilă este pentru întreaga familie și adaptarea la situația creată o dată cu intrarea copilului la școală. Părintele nu cunoaște suficient de bine limba țării în care a imigrat se simte „deculturalizat”, iar pentru a nu i se adânci complexul de inferioritate resimțit faţă de grupul la care au aderat prin migrațiune, evită contactul cu școla și profesorii copilului (în special tații). Această situație este interpretată ca o neasumare a sarcinilor parentale, copilul se simte lipsit de sprijin și începe să se creeze o ruptură între tată și fiu. Dacă migrația familiei se produce la vârsta adolescenței copilului, uneori copilul vede separarea de țara de origine ca pe o trădare pe care părinții i-au pregătit-o, el fiind nevoit să se rupă de grupul de coetanei cu care a dezvoltat relații de prietenie și care îi asigură validare și sentimentul de apartenență la grup. Angoasa de singurătate și de izolare pe care adolescentul o trăiește se traduce comportamental prin dorința de a vagabonda și dificultatea de a se implica în activități impuse în mediul familial sau școlar. Intr-o astfel de situație, părinții nu identifică adevăratele emoții ale copilului: teamă, tristețe, etc și pe fondul instabilității lor emoționale- mai sus amintite se exacerbează situațiile conflictuale, care în loc să rezolve, adâncesc probleme.

Dacă au fost prezentate aspectele ce îngreunează parentalitatea în condițiile migrației, considerăm util să precizăm că legătura socială și implicarea comunității în înțelegerea tranziției, manifestarea toleranței și a empatiei, pot preveni izolarea părinților și a copiilor, oferind - prin

\footnotetext{
18 Conceptul de simbioză, descris de Franz Ruppert desemnează: realitate exterioară (forme foarte apropiate de implicare reciprocă în situațiile de viaţă ale indivizilor din aceeași specie sau specii diferite) și realitate interioară (măsura diferită în care aceste implicări sunt reflectate în experiența trăită și comportamentul individului).
} 
educație și susținere morală șansa reconstrucției parentalității pe cadrele impuse de societatea care primește familia.

Raportarea la sărăcie și la modul în care aceasta afectează practica parentalității, presupune corelații între starea de sărăcie și accesul la beneficii și servicii sociale, în încercarea de a evidenţia faptul că nu întotdeauna sărăcia afectează în mod semnificativ relația dintre părinte și copil, adică, în aşa grad încât să reducă șansele copilului la socializare secundară (școala) sau la servicii de sănătate și prin aceasta să crească riscul de excluziune socială. În acest context amintim situațiile în care parentalitatea este sprijinită prin servicii sociale dedicate copilului sau familiei:

- centre de zi pentru copii- care degrevează părinții, câteva ore zilnic zilnic de sarcinile parentale, perioadă în care părintele poate dedica acest timp asigurării subzistenței; ca și activităţi desfășurate de copil în cadrul centrului de zi amintim socializarea cu copii de aceeași vârstă sau de vârste apropiate, efectuarea temelor școlare, servirea mesei, consiliere psihologică. Considerăm important a sublinia faptul că centrul de zi NU este un serviciu de tip afterschool, ci un serviciu social. Astfel, accesarea centrului de zi presupune și asumarea de către părinţi a unor responsabilităti precum: participarea la ședințe de consiliere - psihologică, socială, juridică- în funcție de situație, participarea la programe de educație parentală; acestea din urmă permit experimentarea unui mediu cald şi sigur în care ei pot să se simtă în largul lor atunci când îşi împărtăşesc experienţele şi învaţă despre rolul de părinte (Cojocaru Ș. [2, p. 237]), își dezvoltă abilități de părinte, descoperă noi modalităţi de comunicare asertivă cu copilul, de disciplinare pozitivă, de gestionare a stresului și a furiei, etc, construiesc un mediu al încrederii şi sprijinului reciproc între părinţi (rețeaua de sprijin compusă din părinți participanți la cursurile de educație parentală) și nu în ultimul rând învață că pentru a-și asuma eficient rolul de părinte, au nevoie să își înţeleagă propriile nevoi și să își construiască un sine autentic.

- centre de consiliere și sprijin pentru familie și copil- în care, ca și în situația mai sus prezentată părintele învață să acceseze resurse comunitare o dată cu dobândirea unor competențe specifice rolului de părinte;

- beneficii de asistență socială, văzute ca „forme de suplimentare sau de substituire a veniturilor individuale/familiale obținute din muncă, în vederea asigurării unui nivel de trai minimal, precum și o formă de sprijin în scopul promovării incluziunii sociale și creșterii calității vieții anumitor categorii de persoane ale caror drepturi sociale sunt prevazute expres de lege" (Legea nr. 292/2011 a asistentei sociale, art. 7. [9]), cum ar fi: beneficii de asistență socială pentru susținerea copilului și familiei; pentru sprijinirea persoanelor cu nevoi speciale; pentru situații deosebite; beneficiile se acordă în bani sau în natură (ajutoare materiale constând în bunuri de folosință personală sau îndelungată și alimentare, acordate individual ori în cadrul unor programe destinate facilitării accesului la educație, sănătate şi ocupare) și cuprind alocaţii, indemnizații, ajutoare sociale și facilități (asigurarea plății unor contribuții de asigurări sociale și/sau asimilarea unor perioade de contribuție, facilități de acces la mediul fizic, informațional și comunicațional, facilități fisscale).

Strategiile de incluziune sociale văd în aceste beneficii o modalitate de asigurare a subzistenței, un mijloc de reducere a inegalităților dintre persoane, de includere în rețelele de sprijin comunitar; ele nu sunt oferite ca sprijin unitar, ci alături de servicii integrate, constatându-se că vulnerabilitatea părintelui înseamnă şi vulnerabilitatea copilului, iar aceasta nu înseamnă doar sărăcie și condiții insuficiente de trai dar și riscul de a nu fi școlarizat sau de a abandona școala, probleme de sănătate și altele.

Crearea serviciilor integrate sunt promovate prin politicile publice în acord cu termenul de responsabilitate parentală. Astfel se consideră că sprijinul pe care îl primește părintele reduce din stresul cotidian generat de necesitatea de a asigura copilului o existenţă decentă, care să permită formarea unui viitor adult sănătos și echilibrat dar în primul rând îl face mai responsabil, înțelegând prin aceasta angajamentul personal pe care părintele îl ia, o interiorizare a obligației, subiectul fiind dator pentru faptele sale și față de persoanele pe care- din punct de vedere juridic și moral le are în grijă. Acolo unde familia lărgită consideră că nu are resursele necesare pentru a sprijini 
parentalitatea sau, acolo unde familia lărgită nu există, în baza unuia dintre cele mai importante principii pe care sistemul de asistenţă socială se bazează- principiul subsidiarităţii- statul intervine.

În condițiile gravei deteriorări a condiţiilor de trai şi a sărăciei accentuate, numeroase familii îşi lasă copiii în instituţii, ca o măsură temporară sau permanentă. Într-unul din documentele care fac parte din studiile de fundamentare care au stat la baza elaborării Strategiei naţionale privind incluziunea socială şi reducerea sărăciei 2015-2020 şi Acordul de parteneriat pentru perioada de programare 2014-2020 (Stănculescu M.S., Grigoraş V., Teşliuc E., Pop V. [20, p. 16]) se amintește faptul că după anul 2007, când România a aderat la Uniunea Europeană, până în 2015, în mod constant, copiii și tinerii au avut, de departe, cel mai crescut risc de sărăcie dintre toate grupele de vârstă. Sărăcia monetară, cuplată cu lipsa accesului la serviciile sociale de bază (inclusiv de sănătate şi educaţionale) şi cu o piaţă a muncii ineficientă, creşte riscul ca aceşti copii să se confrunte cu sărăcie persistentă şi când vor deveni adulţi. Studiul amintit subliniază că tipul de gospodărie cu cea mai mare probabilitate de a se confrunta cu lipsuri materiale severe este cel format din doi adulţi şi trei sau mai mulţi copii; membrii unei astfel de gospodării $(96 \%)$ nu îşi permit o vacanţă de o săptămână departe de casă şi, în plus, aproape jumătate nu îşi permit nici acoperirea cheltuielilor neprevăzute, o masă pe bază de carne o dată la două zile, evitarea restanţelor şi o maşină. Doar 4\% dintre copiii din sistemul de protecţie provin din familii care nu sunt sărace (cu un venit lunar pe membru de familie de peste 400 lei), şi încă $6 \%$ sunt la risc de sărăcie (sărăcie relativă), în timp ce restul de 90\% sunt din familii sărace, sau extrem de sărace (Stănculescu M.S., Grigoraş V., Teşliuc E., Pop V. [20, p. 138]).

Cei mai mulţi copii din sistemul de protecţie au trăit în familii în sărăcie extremă sau în sărăcie, înainte de a intra în sistem, iar înainte de a fi separaţi de familie, copilul şi familia nu au avut acces corespunzător la beneficii sociale şi în niciun caz la servicii suport- din diverse motive: inaccesibilitate generată de distanța mare dintre locuința de domiciliu și sediul administrației locale responsabile cu acestea - în orice județ există localități izolate, serviciile publice de asistență socială nu dețin suficient personal de specialitate care să identifice și să consilieze social familia aflată în dificultate, părinții au un acces redus la informații - uneori din cauza faptului că sunt analfabeți, sau, în alte situaţii- părinţii nu îşi permiteau costurile administrative asociate sau aveau diferite amenzi şi impozite neplătite.

Studiile demonstrează că în puține dintre cazuri doar sărăcia -instalată în timp : nivel redus al studiilor care au împiedicat inserția pe piața muncii, diferite dizabilități ale părinților și asocierea acestora cu lipsa familiei lărgite sau a rețelei de sprijin, etc sau brusc- de exemplu singurul părinte întreținător al familiei și-a pierdut locul de muncă) afectează nivelul de trai al familiei, însemnând prin aceasta imposibilitatea părinților de a asigura nevoi de bază ale copilului (hrană, locuință, etc)a dus la separarea copilului de părinți, de cele mai multe ori ea venind împreună cu ignorarea necesităților zilnice ale copilului - de la privarea de hrană sau de somn, cât și la celelalte tipuri de nevoi regăsite în piramida lui (Maslow, A, 2008: 170-180): a nu vorbi copilului, a nu-i oferi atenţie și dragoste, neasigurarea măsurilor de supraveghere și protecție, a nu îi permite să se joace, să exploreze, etc.

J. Bowlby [1, p. 81-106] vorbind despre copilul mic separat de mamă înainte de împlinirea vârstei de 3 ani vorbește despre fazele pe care le dezvoltă acesta: revoltă- invadată de episoade de furie și lacrimi, deznădejde- când își pierde speranța că mama va mai reveni, pentru ca în final, să se producă detașarea: copilul pare să își uite mama, iar atunci când aceasta se întoarce/îl vizitează este dezinteresat de persoana acesteia și pare că nu o recunoaște. J. Bowlby subliniază faptul că în situația în care perioada de separare durează mai mult de șase luni, sau când separările s-au repetat, copilul poate ajunge la un stadiu avansat de detașare și chiar poate rămâne detașat permanent, fără să-și mai poată recupera afecțiunea față de părinții săi. Dacă ne gândim că de calitatea experiențelor pe care le-am avut în copilărie depind caracteristicile pe care le vom avea ca adulți (Cury A. [3, p. 119]) putem previziona din păcate o personalitate rigidă a viitorului adult, insatisfacție pe toate planurile vieții, grad scăzut de sociabilitate și stimă de sine scăzută. 
În contextul în care axele parentalității- cea subiectivă- materializată de obicei prin reprezentări și povești despre copil ce permit emoții și prin acestea sintonie între copil și părinte și axa practicării parentalității- care include aspecte concrete ale vieții cotidiene, îngrijirea copiluluisunt extrem de slab reprezentate în contextul instituționalizării copilului, consecințele- mai întâi asupra copilului, dar și asupra părinților pentru care parentalitatea apare în cele din urmă doar prin filiație, pot fi vizibile și la vârsta la care copilul a atins maturitatea.

Prin cele de mai sus ne-am dorit evidențierea faptului că parentalitatea este influențată de contextul economic și socio-cultural. Fiecare societate își elaborează o concepție proprie despre copil, despre nevoile sale, despre rolul părinților. Părinții imigranți vin cu modele din țara de origine, iar suprapunerea acestora peste modelele elaborate de către specialiști într-o cultură diferită poate provoca neînțelegeri. Sărăcia, lipsa educației, problemele de sănătate nu mai interesează doar familiile afectate de acestea, politicile publice justificându-se din ce în ce mai mult prin faptul că parentalitatea nu este doar o chestiune ce privește în exclusivitate copiii și părinții acestora; dacă părinții nu își asumă responsabilitățile specifice, nu urmează reguli de educație, întreaga societate este în pericol și intervine în dinamica axelor parentalității, pentru că măsurile preventive nu au fost aplicate.

\section{Bibliografie}

1. Bowlby John. Crearea și ruperea legăturilor afective. Ed. Trei, București, 2016.

2. Cojocaru Ştefan. Manualul Educatorului Parental. HoltIS, UNICEF, Iaşi: Expert Projects, 2015.

3. Cury Augusto. Eliberează-te din temnița emoțională. Ed. For You, București, 2013.

4. Drăgan Ioan. Modernizare şi dezvoltare. Bucureşti. 2002.

5. Ghebrea Georgeta. Familia şi politica familială, Bucureşti. 2003.

6. Giblin Les. Arta dezvoltării relaţiilor interumane. Bucureşti: „Curtea Veche”, 2000.

7. Goody Jack. Familia europeană.O încercare de antropologie istorică. Polirom, Iaşi, 2003.

8. Iluţ Petru. Sociopsihologia şi antropologia familie. Iaşi: Polirom, 2005.

9. Legea nr. 292/2011 a asistentei sociale.

10. Mitrofan I. şi Mitrofan N. Elemente de psihologie a cuplului. Bucureşti: Şansa SRL, 1994.

11. Maslow Abraham. Motivație și personalitate. București: Ed. Trei, 2008.

12. Moro Marie-Rose. Parents en exil. Psychopathologie et migrations. Paris, PUF, 1994.

13. Roudinescu Elisabeth. Familia în dezordine. București: Ed. Trei, 2006.

14. Rudică Tiberiu. Psihologia frustraţiei. Ed. a II-a. Iaşi: Polirom, 2006.

15. Ruppert Franz. Simbioză și autonomie. Traumă și iubire dincolo de complicațiile simbiotice. Ed. Trei, București, 2015.

16. Sellenet Catherine. Parentalitatea pe înțelesul tuturor. Pertinența și derivele unui concept. Iași: Ed. Universității Al. I. Cuza, 2013.

17. Siegel Daniel, Hartzell Mary. Parentaj sensibil și inteligent. Să ne înțelegem pe noi înșine, pentru a crește copii fericiți. București: Ed. Herald, 2017.

18. Simion Maria. Familia în Europa între 1960 şi 2000. Calitatea Vieţii, XIII, 2002, nr.1-4, 2002.

19. Solis-Ponton L. (coord). Parentalitatea, Provocare pentru mileniul. București: Ed. Trei, 2017.

20. Stănculescu Manuela Sofia, Grigoraş Vlad, Teşliuc Emil, Pop Voichița (coord.). România: Copiii din sistemul de protecție a copilului. București: Ed. Alpha MDN, 2016.

21. Van Gennep Arnold. Riturile de trecere. Iași: Polirom, 1996. 